MARIUSZ GOŁDYSIAK

Instytut Stosunków Międzynarodowych UMK

\title{
Działalność Misji Unii Europejskiej o pomocy granicznej dla Ukrainy i Mołdawii (EUBAM) na tle naddniestrzańskiego konfliktu
}

$\mathbf{N}$ addniestrzańska Republika Mołdawska (NRM), bardziej znana jako Naddniestrze, usytuowana jest w południowo-wschodniej Europie. Biegnie ona wąskim pasem o długości około $202 \mathrm{~km}$ i szerokości od kilku do kilkunastu kilometrów. Terytorium NRM wynosi $4163 \mathrm{~km}^{2}$. W większości jest to obszar równinny nie mający dostępu do morza. Wschodnia i północna długość granicy Naddniestrza z Ukrainą wynosi $405 \mathrm{~km}$ i pokrywa się z dawną granicą Mołdawskiej Socjalistycznej Republiki Radzieckiej. Natomiast główna część zachodniej granicy z Mołdawią ma długość $411 \mathrm{~km}$ i przebiega wzdłuż Dniestru ${ }^{1}$.

Naddniestrze formalnie stanowi część Republiki Mołdawskiej, lecz de facto od początku lat 90. w następstwie konfliktu zbrojnego i rosyjskiej pomocy udzielonej separatystom ${ }^{2}$, znajduje się pod kontrolą samozwańczego reżimu, na którego czele stoi Igor Smirnow33. Mimo usilnych starań NRM nie została oficjalnie uznane przez żaden demokratyczny kraj świata. „Zamrożony konflikt" w tym regionie już od kilkunastu lat stanowi poważne wyzwanie dla wspólnoty międzynarodowej z Organizacją Bezpieczeństwa i Współ-

\footnotetext{
Атлас. Приднестровская Молдавская Республика. Исторя, Тираспол 2005, s. 60.

2 Więcej na temat konfliktu w Naddniestrzu - Перепелица Г.Н, Конфликт в Приднестровье (причины прогноз развития и проблемы урегулирования), Киев, s. 10-25.

3 Por. sylwetkę Igora Smirnowa na http://www.lenta.ru:8085/lib/14162428/ [31.03.2007].
} 
pracy w Europie na czele, jednakże do dnia dzisiejszego nie udało się znaleźć odpowiedniego rozwiązania. Na jak najszybszym uregulowaniu tej kwestii powinno zależeć szczególnie Ukrainie i Mołdawii, gdyż konflikt wokół Naddniestrza staje na przeszkodzie w nawiązaniu normalnej współpracy granicznej między obu państwami. Większe zainteresowanie powinna okazać także Unia Europejska, która w wyniku rozszerzenia o Rumunię i Bułgarię w styczniu tego roku znalazła się w bezpośredniej bliskości obszaru destabilizującego sytuację w tej części Europy. Główne zagrożenie wynika z faktu, że kontrolowana przez „separatystów” republika jest źródłem przemytu na masową skalę głównie produktów naftowych, alkoholu, papierosów i produktów spożywczych. Poza tym w dalszym ciągu znajdują się tutaj dość duże składy pocisków i amunicji „otrzymane w spadku” po Związku Radzieckim oraz fabryki zajmujące się produkcją sprzętu wojskowego. Brak kontroli nad działaniami tamtejszych elit w konsekwencji może doprowadzić do nieoczekiwanych następstw.

Ukraina, będąc od połowy lat 90. jednym z gwarantów procesu urągulowania naddniestrzańskiego konfliktu, popierała integralność terytorialną i suwerenność państwową Republiki Mołdawskiej. Jednak z drugiej strony nie podejmowała żadnych realnych kroków w celu wykorzystania swojego potencjału dla osiągnięcia porozumienia. Kijów zachowywał się wymijająco, próbując równoważyć swoje stosunki z Rosją i Zachodem, a co za tym idzie, rzadko okazywał decydujące wsparcie którejś ze stron. Sytuacja zmieniła się po objęciu urzędu prezydenta przez Wiktora Juszczenkę ${ }^{4}$. Nowe kierownictwo Ukrainy od samego początku jako jeden z głównych priorytetów polityki zagranicznej określiło podjęcie realnych kroków dla likwidacji „punktu zapalnego" u swych południowo-zachodnich granic. Ostateczne uregulowanie tego problemu stanowiło element składowy nowej strategii geopolitycznej Kijowa, chcącego odgrywać większą rolę w polityce regionalnej ${ }^{5}$.

Juszczenko już w pierwszych tygodniach swojego urzędowania nawiązał ściślejszą współpracę z prezydentem Mołdawii V. Voroninem. Obaj spotkali się w Kijowie na początku marca 2005 r. We wspólnej deklaracji potwierdzili gotowość przeprowadzenia konsultacji w celu rozwiązania szeregu kwestii praktycznych dotyczących naddniestrzańskiego konfliktu, poczynając od uregulowań celnych.

${ }^{4}$ W. Juszczenko pokonał popieranego przez Rosję Wiktora Janukowycza w powtórzonej drugiej turze wyborów, która odbyła się 26 grudnia 2004 r. Wcześniejsza została unieważniona, gdyż władzom udowodniono oszustwa wyborcze, w wyniku których doszło do „Pomarańczowej Rewolucji”.

${ }^{5}$ Безп'ятчук Ж., Придністров'я: драма демократіі чи фіаско дипломатіi?, День, № 235, 20 грудня 2005. 
Na szczycie GUUAM, który odbył się 22 kwietnia 2005 r. w Kiszyniowie, Ukraina po raz pierwszy od czasu wyniknięcia naddniestrzańskiego problemu przedstawiła konkretne inicjatywy odnośnie jego rozwiązania. Projekt Uregulowanie poprzez demokratyzacje znany bardziej jako Plan Juszczenki ${ }^{6}$ składał się z siedmiu kroków, a jednym z nich była zgoda Ukrainy na ustanowienie misji obserwacyjnej wzdłuż granicy z Mołdawią ${ }^{7}$.

W czerwcu 2005 r. obaj prezydenci zwrócili się z wspólną prośbą do Unii Europejskiej w sprawie otrzymania pomocy odnośnie kontrolowania mołdawsko-ukraińskiej granicy, przez którą przechodzi większa część kontrabandy z Naddniestrza. Wobec pozytywnej reakcji Brukseli w listopadzie 2005 r. została skierowana tam Misja Unii Europejskiej o pomocy granicznej (EUBAM).

Drugim istotnym elementem zmierzającym do zacieśnienia ukraińsko-mołdawskiej współpracy była unifikacja procedur celnych. W tym miejscu należy wspomnieć, że relacje handlowe Mołdawii i Naddniestrza zostały stworzone w oparciu o protokół z 1996 r. Zakładał on likwidację posterunków celnych NRM na wewnętrznej granicy, stworzenie wspólnych mołdawsko-naddniestrzańskich przejść z Ukrainą i ujednolicenie prawa celnego. W czasie, kiedy Mołdawia wywiązała się ze swoich zobowiązań, strona naddniestrzańska nie wypełniła żadnego punktu porozumienia. Taki stan rzeczy w prosty sposób umożliwił tamtejszym przedsiębiorstwom legalny eksport towarów bez konieczności płacenia podatków w Mołdawii. Ponieważ Kiszyniów zgodził się także zrezygnować z opłat od towarów przeznaczonych dla separatystycznej republiki, a przewożonych w większości przez granicę z Ukrainą, rozwinął się bardzo dochodowy interes związany z reeksportem. Proceder ten polega na sprowadzaniu ogromnych ilości towarów (znacznie przekraczających popyt wewnętrzny), z których władze w Tyraspolu nie pobierają żadnych opłat celnych ani podatków. Następnie wystarczy je przewieźć przez niekontrolowaną granicę wewnętrzną do Mołdawii, a z ich sprzedażą nie ma problemów, gdyż są one tańsze aniżeli te dostępne na lokalnym rynku. Ogromne zyski z tej działalności trafiają do kieszeni naddniestrzańskich przedsiębiorców, a także ich rosyjskich, ukraińskich i mołdawskich „partnerów handlowych”. Pierwsze próby przeciwdziałania kon-

\footnotetext{
“ Znany także pod nazwą „Planu Poroszenko”, ponieważ w znacznej części został opracowany przez byłego szefa Narodowej Rady Bezpieczeństwa i Obrony Ukrainy, Petra Poroszenko.

7 Рязанова М.Л, Придністровский конфлікт - зміни формату врегулювання, Стратегична панорама, Т. 2, 2005, s. 87-88.

8 Неясное будущее Молдовы, Доклад № 175 Европа, 17 августа 2006, s. 3.

9 Молдова: региональные напряженные отношения в Приднестровье, Доклад № 157 МГПК Европа, Кишинев/Брюссель 17 июня 2004, s. 20.
} 
trabandzie zostały podjęte przez Mołdawię i Ukrainę jeszcze w 2004 r., kiedy to strony uzgodniły stosowne porozumienie, jednakże Kijów nie wcielił go w życie. Tym niemniej 30 grudnia 2005 r. premierzy obu państw - Wasilij Tarlew i Jurij Jechanurow podpisali wspólną deklarację o ponownej realizacji wcześniejszych ustaleń dotyczących przepływu towarów w oparciu o wyłącznie mołdawskie dokumenty celne. Na jego mocy ukraińskie władze zobowiązały się do niewpuszczania na swoje terytorium towarów eksportowanych przez naddniestrzańskie kompanie, które nie zostały na stałe lub czasowo zarejestrowane $\mathrm{w}$ Kiszyniowie ${ }^{10}$. Proces rejestracji nie był ani skomplikowany, ani drogi. Poza tym stała rejestracja w zamian za płacenie VAT i podatku dochodowego dawała możliwość preferencyjnego handlu z Unią Europejską. Z kolei czasowa rejestracja nie pozwalała na dostępu do rynku zjednoczonej Europy, ale nie pociągała za sobą obowiązku wnoszenia żadnych opłat do mołdawskiego budżetu. Kiszyniów zobowiązał się także do zwrócenia przewoźnikom opłat importowych jeśli wwożą oni towary do Mołdawii ${ }^{11}$. Choć realizacja porozumienia nieco przeciągnęła się $\mathrm{w}$ czasie to od 3 marca 2006 r. zaczęło ono obowiązywać.

Nowe regulacje natychmiast spotkały się ze stanowczym sprzeciwem I. Smirnowa, który w swym oświadczeniu stwierdził, że „wyrządziły one poważne straty finansowe gospodarczym podmiotom Naddniestrza, a także nadszarpnęły wiarę mieszkańców regionu w obiektywność i bezstronność Ukrainy jako mediatora". Negatywna była także reakcja rosyjskiego Ministerstwa Spraw Zagranicznych, czego potwierdzeniem może być wezwanie do ponownego przeanalizowania podjętych kroków, gdyż jak to stwierdzono „Kiszyniów i Kijów po raz kolejny próbują zastosować nacisk ekonomiczny na Tyraspol w celu zmuszenia go do politycznej kapitulacji w kwestiach naddniestrzańskiego uregulowania" ${ }^{12}$. Natomiast rosyjska Duma Państwowa stwierdziła nawet, że nowy reżim celny „może doprowadzić do katastrofy humanitarnej w Naddniestrzu"13.

Mając poparcie Moskwy, I. Smirnow zaczął rozpowszechniać informacje o „blokadzie ekonomicznej” regionu. Niemal codziennie dochodziło do demonstracji protestu $\mathrm{w}$ różnych miastach położonych na lewym brzegu Dniestru, podczas których manifestujący domagali się, aby „nie dopuścić do

\footnotetext{
${ }^{10}$ Максименко И., Неконкретные переговоры: Почему Тирасполь боится блокады?, День, № 16,4 февраля 2006.

${ }^{11}$ Неясное будущее Молдовы, dz.cyt., s. 11.

${ }^{12}$ Украина ввела в действие соглашение о новом порядке проходения грузов через границу с молдовой, dostępne: http://www.conflict.md/stiri.php?ID=480 [21.04.2007].

${ }^{13}$ Парламент РМ обеспокоен опасным развитием ситуации в приднестровском регионе, dostępne: http://www.conflict.md/stiri.php?ID=507 [21.04.2007].
} 
gospodarczej i politycznej agresji na naddniestrzańskiej ziemi” oraz zwracali się z prośbą do Rosji o uznanie ich państwowości ${ }^{14}$.

Rzeczywista sytuacja na miejscu wyglądała zupełnie inaczej. Zaniepokojony wprowadzeniem nowych zasad lider samozwańczej republiki nakazał lokalnym przedsiębiorcom przerwanie eksportu, które miało stanowić odpowiedź na usztywnienie procedur. Zatem doszło do „samoblokady” z naddniestrzańskiej strony. Wielu ekspertów jest zgodnych, że obawiając się utraty kontroli nad przepływem towarów, I. Smirnow swoim oświadczeniem o blokadzie próbował przede wszystkim przywrócić wcześniejsze status quo ${ }^{15}$.

Początkowe zamieszanie zostało spotęgowane brakiem stosownych informacji, ponieważ ani Kiszyniów, ani Kijów nie podały oficjalnego celu wprowadzenia nowych regulacji na granicy. W związku $\mathrm{z}$ tym środki masowego przekazu nie mając pewnych wiadomości, zaczęły rozpowszechniać wersję o rzekomej „katastrofie humanitarnej”. Dopiero w następstwie stanowczej reakcji Wysokiego Przedstawiciela ds. Wspólnej Polityki Zagranicznej i Bezpieczeństwa UE Javiera Solany, Ukraina wydała stosowne oświadczenie. Natomiast ze strony mołdawskiej uczynił to 6 marca premier Wasilij Tarlew ${ }^{16}$. Mimo tych początkowych zawirowań, działania podjęte przez Ukrainę i Mołdawię zostały pozytywnie przyjęte przez Unię Europejską, USA i OBWE. Między innymi komisarz ds. stosunków zewnętrznych i polityki sąsiedztwa UE Benita Ferrero-Waldner stwierdziła, że „Komisja Europejska uznaje przyjęte środki za służące zapewnieniu przejrzystości operacji na granicy mołdawsko-ukraińskiej"17.

W połowie marca Rada Najwyższa NRM podjęła decyzję o zakończeniu blokady granicy z Ukrainą. Niemniej jednak rosyjskie kręgi polityczne skupione wokół proprezydenckiej partii „Jedna Rosja” postanowiły wysłać do Naddniestrza kolumnę 23 ciężarówek z „pomocą humanitarną”, ponieważ uważały, że Rosjanom tam mieszkającym potrzebne są żywność oraz leki ${ }^{18}$. Ukraina stanowczo temu zaprzeczyła i nazwała całą inicjatywę akcją propagandową ${ }^{19}$.

W wyniku pasywnej postawy I. Smirnowa proces rokowań dotyczących uregulowania naddniestrzańskiego problemu został wstrzymany na osiem miesięcy. Tyraspol miał nadzieję, że nowy ukraiński rząd pod

\footnotetext{
${ }^{14}$ Корниичук О., Борьба нервов, День, 40, 14 марта 2006.

${ }^{15}$ Солодкии С., Мнимая блокада, День, 38, 10 марта 2006.

${ }^{16}$ Неясное будущее Молдовы, dz.cyt., s. 11

${ }^{17}$ Корниичук О., Борьба нервов, День, 40, 14 марта 2006.

${ }^{18}$ Więcej na ten temat: Гетьманчук A., «Самоблокада» по российскому сценарию?, Зеркало Недели, 13, 8-14 апреля.

${ }^{19}$ Форпост нестабильности: Каковы причины приднестровского кризиса?, День, 50, 28 марта 2006.
} 
kierownictwem Wiktora Janukowycza przywróci „stare” przepisy, jednakże ten zapowiedział wspieranie integralności terytorialnej Republiki Mołdawskiej i utrzymał wcześniejsze postanowienia.

Niemniej jednak same regulacje celne nie zmienią sytuacji w tym regionie. Ponad 200 z 300 znajdujących się tutaj kompanii zarejestrowało swoją działalność w Kiszyniowie, z czego około połowa z nich na stałe. Wynika to przede wszystkim z chęci osiągnięcia korzyści wypływających z preferencji handlowych z UE, gdyż naddniestrzańskie firmy już dawno mogły zarejestrować się w Kiszyniowie i otrzymywać tamtejsze dokumenty celne. Z kolei protokół o współpracy gospodarczej między Federacją Rosyjską a NRM z maja 2006 r. nadaje kompaniom z lewego brzegu Dniestru ulgowe taryfy eksportowe do Rosji. Nawet czasowo zarejestrowane w Kiszyniowie bez żadnych problemów mogą kierować swoją produkcję przez Ukrainę na rosyjski rynek ${ }^{20}$.

Pozytywne rezultaty może przynieść tylko połączenie nowych przepisów granicznych $\mathrm{z}$ innymi rozwiązaniami. Jednym z nich jest $\mathrm{z}$ pewnością misja obserwacyjna EUBAM, która rozpoczęła swoją działalność na mołdawsko-ukraińskiej granicy 30 listopada 2005 r.

Już dawno pojawiały się propozycje, aby UE fizycznie wzięła udział $\mathrm{w}$ uregulowaniu naddniestrzańskiego konfliktu, ale dopiero EUBAM stanowi wyraźny dowód zaangażowania Zjednoczonej Europy w próbę rozwiązania tego problemu.

Misja została powołana dla zwiększenia efektywności służb granicznych i celnych obu państw, aby przeciwdziałać „takim działaniom przestępczym jak handel ludźmi, kontrabanda, handel bronią i machinacje celne", jak również ma "odegrać ważna rolę $\mathrm{w}$ stworzeniu wstępnych warunków w poszukiwaniu dróg pokojowego uregulowania naddniestrzańskiego konfliktu"²1. Głównymi celami Misji są: praca wspólnie z Mołdawią i Ukrainą dla zharmonizowania standardów i procedur zarządzania granicą z normami obowiązującymi na terytorium państw Unii Europejskiej, przyczynianie się do podnoszenia profesjonalizmu mołdawskich i ukraińskich służb celnych i granicznych w działaniach operacyjnych, rozwijanie system analizy ryzyka, polepszanie wzajemnych stosunków pomiędzy służbami granicznymi i celnymi, a innymi organami porządkowymi, wspieranie współpracy transgranicznej $^{22}$. Jest ona organem doradczym, technicznym, pozbawionym uprawnień wykonawczych, który został powołany na dwa lata. Na jej czele stoi wę-

\footnotetext{
${ }^{20}$ Неясное будущее Молдовы, dz.cyt., s. 12

${ }^{21}$ Tamże, s. 7

${ }^{22} \mathrm{Na}$ oficjalnej stronie internetowej EUBAM, dostępne: http://www.eubam.org/index.php? action=group\&group=3\&sid=luygsq6d0k7odkwz1fi40qadlsp0zgfa [21.04.2007]
} 
gierski generał Ferenc Banfi. W Misji pracuje 177 osób, spośród których 103 stanowi personel międzynarodowy z 17 państw członkowskich UE oraz z trzech krajów WNP, a także 74 współpracowników z Mołdawii i Ukrainy. Z ramienia UE uczestniczą: Austria, Belgia, Czechy, Dania, Estonia, Finlandia, Francja, Niemcy, Węgry, Włoch, Łotwa, Litwa, Polska, Portugalia, Rumunia, Słowacja i Wielka Brytania ${ }^{23}$. Pod względem logistycznym posiada ona sztab generalny usytuowany w Odessie (opracowuje i ocenia zebrane informacje) oraz 7 biur terenowych na granicy ukraińsko-mołdawskiej. Po stronie mołdawskiej są to: Kiszyniów (kontrola wewnętrznej granicy między Naddniestrzem i pozostałą częścią Mołdawii), Otacz i Basarabiaska, natomiast po ukraińskiej: Timkowo-Slobodka, Platonowo, Cuciurgan oraz Odessa (kontroluje ukraińskie porty czarnomorskie Odessa i Iliczewsk). Budżet Misji do końca 2007 r. wynosi 20,2 mln euro. Jednym z głównych projektów koordynowanych przez Misję jest tzw. BOMMOLUK, który ma na celu poprawę kontroli na mołdawsko-ukraińskiej granicy, a jego realizacja ma kosztować $9 \mathrm{mln}$ euro. Pierwsza część tego przedsięwzięcia polega na zakupie sprzętu, rozwoju systemu analizy ryzyka i szkoleniu urzędników ${ }^{24}$.

Podstawowym zadaniem ekspertów EUBAM jest nie tyle samodzielne patrolowanie granic, co kontrolowanie, w jaki sposób strażnicy graniczni oraz urzędnicy celni obu państw sprawdzają dokumenty i rewidują środki transportu. Mogą także towarzyszyć pogranicznikom podczas patroli, obserwować procedury celne oraz przyczyniać się do lepszej współpracy i wymiany informacji między służbami Mołdawii i Ukrainy. Brak uprawnień wykonawczych co prawda uniemożliwia członkom Misji np. kontrolowanie podejrzanych osób, ale nie pozbawia prawa do udzielania rekomendacji i żądania, by niektórzy przekraczający granicę zostali sprawdzeni w ich obecności.

$\mathrm{Na}$ dzień dzisiejszy najważniejszym osiągnięciem EUBAM jest wkład w realizację deklaracji mołdawsko-ukraińskiej wprowadzającej nowe regulacje celne. Zdaniem członków Misji ich wprowadzenie zwiększyło przejrzystość przepływu towarów na granicy z Naddniestrzem. Odegrała ona także ważną rolę $\mathrm{w}$ pierwszych dniach obowiązywania nowych zasad, gdyż stanowczo zaprzeczała jakoby działania Ukrainy doprowadziły do „blokady ekonomicznej” i wywołały „katastrofę humanitarną”"

\footnotetext{
${ }^{23}$ Większość z tych państw oddelegowała specjalistów różnych służb jako swój bezpośredni wkład w działalność Misji. Справка о деятельности Миссии Европейского Союза, dostępne: http://www.eubam.org/index.php?action=group\&group=21\&sid=luygsq6dok7odk wz1fi40qadlsp0zgfa [21.04.2007].

${ }^{24}$ Tamże.

${ }^{25}$ Достижения Миссии ЕС, dostępne: http://www.eubam.org/index.php?action=group \&group=21\&sid=luygsq6d0k7odkwz1fi40qadlsp0zgfa [21.04.2007].
} 
Informacje zebrane przez ekspertów w trakcie ich dotychczasowej pracy świadczą, że separatystyczna republika nie jest „czarną dziurą" w systemie handlu bronią i narkotykami, jak przez długi czas twierdzili krytycy reżimu I. Smirnowa. Nie znaleziono żadnych dowodów będących potwierdzeniem istnienia zorganizowanej kontrabandy broni i wykryto tylko nieznaczny zakres handlu narkotykami, jednakże przedstawiciele Misji nie mogą zagwarantować, że tego rodzaju działalność w ogóle nie ma miejsca ${ }^{26}$.

W tym samym czasie jednak ujawniono proceder przemytu na masową skalę przede wszystkim towarów konsumpcyjnych, w szczególności mrożonego mięsa. Zgodnie z raportem Misji, w ciągu pół roku od października 2005 do marca 2006 naddniestrzańskie kompanie zaimportowały 40 tys. ton mięsa z kurczaków, co odpowiada $67 \mathrm{~kg}$ na osobę, kiedy np. w Niemczech jest to około $5,6 \mathrm{~kg}$. Stąd wniosek, że większa jego część była następnie nielegalnie reeksportowana, a zyski z tej działalności mogły sięgać dziesiątków milionów euro rocznie ${ }^{27}$. Poza tym EUBAM stwierdziła poważne niedociągnięcia w kwestiach zarządzania po obu stronach granicy oraz opracowała liczne rekomendacje dla rządów w Kiszyniowie i Kijowie mające służyć podniesieniu standardów granicznych do norm Unii Europejskiej. Dotyczą one przede wszystkim ulepszenia technologii informatycznych i środków łączności, nadania wszystkim strukturom kompetencji śledczych, poprawy wzajemnej wymiany informacji, rozwinięcia możliwości służących analizie ryzyka i decentralizacji kompetencji ${ }^{28}$.

Działalność EUBAM spotkała się z bardzo pozytywną reakcją ze strony państw, które o nią zabiegały, czyli Ukrainy i Mołdawii, a także wśród przedstawicieli USA i UE. Z kolei Rosja oraz Naddniestrze, które stanowczo zaprotestowały wobec wprowadzenia nowych przepisów celnych, nie przejawiały większego entuzjazmu, ale powstrzymywały się od publicznego wygłaszania krytycznych uwaga pod adresem Misji. Jeden z zachodnich dyplomatów stwierdził, że „nie zapewni ona hermetyczności granicy, ale oczywiście przynosi efekt, rzucając światło na to, co przez nią przechodzi" ${ }^{29}$.

Niemniej jednak w kwestiach walki z kontrabandą i organizowaniu profesjonalnych szkoleń dla mołdawskich i ukraińskich służb granicznych pozostało jeszcze wiele do zrobienia i nie można uznać, że EUBAM całkowicie wypełniła swoje zadania. Łączna długość granicy między Mołdawią i Ukrainą wynosi $1222 \mathrm{~km}$, z czego $955 \mathrm{~km}$ to granica lądowa, a $267 \mathrm{~km}$ wodna. Pracuje na niej 1220 celników i strażników granicznych, a Misja dysponuje

\footnotetext{
${ }^{26}$ Неясное будущее Молдовы, dz.cyt., s. 8.

${ }^{27}$ Достижения Миссии EC, dz.cyt.

${ }^{28}$ Неясное будущее Молдовы, dz.cyt., s. 8.

${ }^{29}$ Tamże.
} 
nieco ponad setką ekspertów podzielonych na grupy, które większość czasu spędzają na punktach kontrolnych ${ }^{30}$. Oprócz tego należy pamiętać, że jest to teren równinny, a budynki mieszkalne często znajdują się na granicy, która miejscami w żaden sposób nie jest oznaczona. Liczne jeziora i rzeki z obszernymi zaroślami z trzciny stanowią doskonałą kryjówkę dla kontrabandystów. Eksperci znający sytuację twierdzą, że granica prawie w całości jest odkryta i bez większych problemów można ją przekroczyć, a zatem przemytnicy raczej nie korzystają z punktów kontrolnych. Poza tym około 95\% towarów przekraczających naddniestrzańską granicę w obu kierunkach przesyłanych jest koleją. EUBAM ma swoich przedstawicieli na dwóch $\mathrm{z}$ trzech przejść kolejowych, ale tylko w Cuciurgan znajduje się odpowiedni sprzęt dla kontroli wagonów, a i on rzadko jest wykorzystywany. Tak więc tym środkiem transportu można przewieźć dosłownie wszystko ${ }^{31}$.

Wobec braku fizycznej możliwości skutecznego kontrolowania granicy, kluczowa jest kwestia analizy ryzyka, która pozwalałaby przewidzieć podejrzane ruchy towarów. Rozwój tego systemu jest jednym z priorytetów Misji, ponieważ właśnie w tej sferze konieczny jest znaczny rozwój, ażeby kontrola graniczna odpowiadała europejskim standardom ${ }^{32}$. Skuteczność takich kroków jest uwarunkowana efektywną wymianą informacji między służbami Mołdawii i Ukrainy, a to zdaniem Ferenca Banfi nie wygląda najlepiej i raczej nie ulegnie szybkiej poprawie. Twierdzi on, że niedostateczna współpraca pomiędzy departamentami obu państw została „odziedziczona” po Związku Radzieckim, w którym proces podejmowania decyzji był scentralizowany, a jedne komórki pozostawały w niewiedzy na temat działań drugich $^{33}$. Poza tym występują także inne przeszkody utrudniające skuteczną analizę ryzyka, np. tylko mołdawska służba celna posiada uprawnienia do prowadzenia czynności śledczych w poważnych przestępstwach. Pozostałe struktury graniczne obu państw mogą zajmować się tylko drobnymi naruszeniami prawa. Pociąga to za sobą sytuację, w której personel tych służb nie ma wystarczającej motywacji dla przeciwdziałania zorganizowanej przestępczości, gdyż i tak ktoś inny będzie zajmował się rozpatrywaniem konkretnych spraw. Strażnicy graniczni często zatrzymują przemytników za niewielkie przewinienia, zamiast spróbować wytropić całą zorganizowaną strukturę nielegalnego handlu. Kolejną kluczową kwestią wpływającą na uszczel-

\footnotetext{
${ }^{30}$ Sprawozdanie przewodniczacej Marianne Mikko z wizyty Prezydium Parlamentu Europejskiego w Mołdowie z 27-30 czerwca 2006 r, s. 6.

${ }^{31}$ Неясное будущее Молдовы, dz.cyt., s. 9.

${ }^{32}$ Годовый отчет EUBAM 2005/2006, dostępne: http://www.eubam.org/files/200-299/284/ Report_Ru.pdf [21.04.2007].

${ }^{33}$ Неясное будущее Молдовы, dz.cyt., s. 9.
} 
nienie mołdawsko-ukraińskiej granicy, a której nie można przemilczeć, jest korupcja wśród celników i strażników obu państw. Niektórzy z nich nie przejawiają inicjatywy, ponieważ nie wiedzą, czy i jak wysoko korupcja utkwiła w ich własnym departamencie ${ }^{34}$.

Misja EUBAM stara się przezwyciężać wszystkie wyżej wymienione przeszkody, ale jak można się domyślać, nie jest to proste. Już teraz należy się zastanowić nad przedłużeniem dwuletniego mandatu EUBAM. Zmiana mentalności pracowników granicznych obu państw może potrwać nawet dziesiątki lat. Poza tym, tylko długoterminowa praca pozwoli stworzyć warunki dla likwidacji licznych struktur przemytniczych stworzonych przez naddniestrzańskie kręgi biznesowe, które czerpią z nich ogromne korzyści kosztem budżetów ukraińskiego i mołdawskiego. Przedkładają one obecny status quo nad prowadzeniem rozmów służących osiągnięciu porozumienia.

Dwie przedstawione inicjatywy Ukrainy i Unii Europejskiej wzbudziły nadzieję, że balans sił zaangażowanych w konflikt istotnie się zmienił. Uszczelnienie przez Kijów systemu celnego zmniejszyło możliwości naddniestrzańskich przedsiębiorców w zajmowaniu się działalnością bez kontroli ze strony Mołdawii. Natomiast Misja EUBAM pomogła okiełznać kontrabandę na kontrolowanym przez separatystyczną republikę odcinku mołdawskoukraińskiej granicy. Jednak nie można liczyć na to, że podjęte środki wystarczą, aby zmusić I. Smirnowa do pójścia na polityczne ustępstwa. Tak długo, jak będzie on miał wsparcie Rosji, nie zostanie osiągnięte konkretne porozumienie. Wobec tego należy przekonać kręgi biznesowe usytuowane na lewym brzegu Dniestru, że współpraca z Mołdawią odpowiada ich własnym interesom. Jest to możliwe tylko w przypadku, gdy wszyscy mieszkańcy kraju uwierzą w jego gospodarczą przyszłość. Niestety, póki co zakres inwestycji zagranicznych w Mołdawii jest bardzo niski, a PKB per capita równy poziomowi Sudanu ${ }^{35}$. Naturalnym więc się wydaje, że w pierwszej kolejności wspólnota międzynarodowa powinna udzielić mołdawskiemu rządowi stosownego wsparcia w reformowaniu kraju. Już teraz wiadomo, że profity uzyskiwane przez elity po obu stronach Dniestru nie pokrywają się z interesami szerokich warstw społeczeństwa. Uregulowanie naddniestrzańskiego konfliktu z pewnością byłoby korzystne dla zjednoczonej Mołdawii, jednak wiele osób nie zdaje sobie $\mathrm{z}$ tego sprawy i nie wie ile ich kosztuje podział kraju ${ }^{36}$.

M A R I U S Z G O Ł D Y S I A K

\footnotetext{
${ }^{34}$ Tamże, s. 10

${ }^{35}$ Tamże, s. 2.

${ }^{36}$ Молдова: Легких решений нет, Отчет 147 - МГПК Европа, Кишинев/Брюссель, 12 августа 2003, s. 1.
} 


\section{The European Union mission's in Ukraine and Moldova activity}

Pridnestrovian Moldavian Republic is located in south-eastern Europe. It borders the Republic of Moldova and Ukraine. Officially the region is a part of the Republic of Moldova, however since the beginning of the 90s it has been under control of a breakaway government led by Igor Smirnoff. Although calling itself independent, it has never been officially recognized by any democratic state. Despite the fact that the frozen conflict existing in the region since a dozen of years constitutes a significant menace for the OSCE and the international community, no solution has been found until now. Pridnestrovie, controlled by separatists, is a land of well-organized smuggling of petrol, alcohol, cigarettes and nutrition.

After the Soviet Union's breakdown, Ukraine was supposed to be a guarantor of the regulation of conflict, but this mission had not been fulfilled until 2005. During the GUAM summit on 22th April 2005, Ukraine, for the first time, presented certain specific solutions. In June 2005, Presidents of Ukraine and Moldova addressed a common demand to the headquarters of the European Union, concerning help in controlling the borders. The EUBAM mission was sent to the region in November 2005. Another field of cooperation between these two states was unification of duty procedures.These regulations met the instant objections of Russian diplomacy, claiming that the economic pressure had been put on Tiraspol in order to force it to political capitulation. Russian Parliament threatened that new duty regime can result in humanitarian catastrophe in the region. Despite these difficulties, the activity of Ukraine and Moldova was approved by EU, USA and OSCE.

The EUBAM's mission main objectives are the security improvement in border areas, better cooperation between Moldavian and Ukrainian administration and implementation of the European procedures. It's an advisory, non-executive organ with 177 employees. 103 of them are members of the international personnel recruited from 17 UE states and 3 states of Commonwealth of Independent States. 74 are the co-workers coming from Moldova and Ukraine. No proof was found confirming the organized weapon contraband, contrary to the illegal meat trade.

The EUBAM's headquarters claim that the insufficient cooperation between the states, lack of motivation and common corruption of the administrative workers are the post-Soviet heritage. The only solution are the long-term projects aiming to persuade both breakaway territories and the Republic of Moldova that only mutual cooperation and common reforms are the way to ensure economic success. 